\title{
Physiological Studies on Growth and Morphogenesis of the Isolated Plant Cell Cultured in vitro V. Artificial Control of the Morphogenetic Polarity
}

\author{
by Tadashi SANDAN* \\ 山段 忠*：遊噰㮌物細胞の生長成形に関する生理学的研究 V. \\ 成形極性の人為的支配
}

Received February 12, 1958

An isolated internodal cell of Nitella or a cell fragment obtained from the internodal cell by strangulation was able to develop a new shoot and rhizoids when it was cultured in agar gel with suitable culture solutions. Furthermore, the morphogenetic polarity was observed in the course of the development. Namely, a new shoot arose from the apical end of the cell or the cell fragment and new rhizoids appeared from the basal end in general. The term of the apical end represents the upper end of the cell when the cell took its position within the mother plant before it was cut off to be used in the experiment, and the term of the basal end indicates the opposite, lower end of the cell. But the morphogenetic polarity was reversed by changing light condition (Sandan, 1955). The present report deals with further experiments in regard to the artificial control of this morphogenetic polarity in the cell of Nitella.

\section{Material and Method}

An isolated internodal cell of Nitella flexilis which was about $4.0 \mathrm{~cm}$. in length and $400 \mu$ in width was applied as material. The material was set in the glass apparatus consisting of two chambers in which the cell is cultured under $\mathrm{pH}$ gradient or IAA concentration gradient. This apparatus which was designed by Prof. N. Kamiya has been used for studies of protoplasmic streaming in Myxomycetes and for studies of osmosis in a single cell of Characeae. In the present work, these two chambers in the apparatus ( $\mathrm{A}$ and $\mathrm{B}$ in Fig. 1) were filled with $0.6 \%$ agar gel which was soaked with culture solution. As culture solution, solutions of various $\mathrm{pH}$ and of IAA in various concentrations were used in the present experiment. In the case of $\mathrm{pH}, \mathrm{McIlvaine}$ 's citrate-phosphate buffer solutions ( $0.01 \mathrm{M}$ citrate, $0.02 \mathrm{M}$ phosphate) of various $\mathrm{pH}$ were used, and in the case of IAA, Sörensen's phosphate buffer ( $\mathrm{pH}$ 6.6, $0.01 \mathrm{M}$ ) was applied as basic solution (control). The gradient of $\mathrm{pH}$ or IAA concentration was attained in the apparatus by using agar gel which was soaked

\footnotetext{
* Biological Institute, Kyoto Liberal Arts University, Fukakusa, Kyoto, Japan. 京都学芸大 学生物学教室
} 


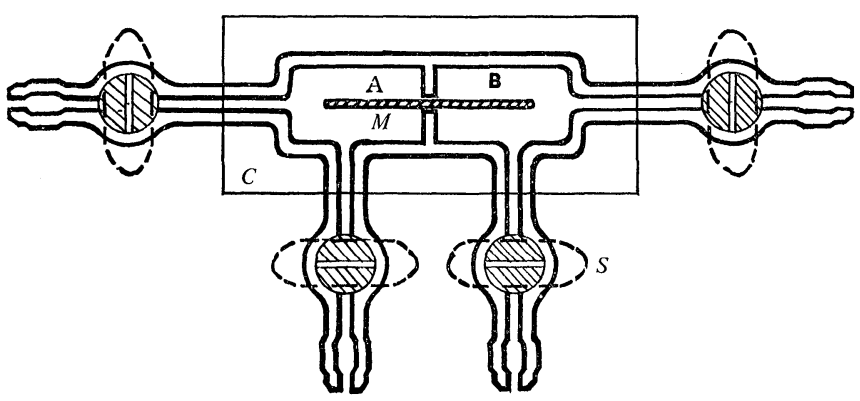

Fig. 1. The double chamber apparatus

A: A chamber (length: $3.0 \mathrm{~cm}$., width: $1.5 \mathrm{~cm}$., height: $1.2 \mathrm{~cm}$. ),

B: B chamber, $\mathrm{C}$ : cover glass, $\mathrm{M}$ : material, $\mathrm{S}$ : stop cock

with the solution of different $\mathrm{pH}$ or different IAA concentration in two chambers of the apparatus. In these two chambers the material, which is divided into two portions by the central glass septum as shown in Fig. 1, was submerged in agar gel. The space between the material and the glass septum was filled with lanolin. Thus, the material was cultured in the apparatus under $\mathrm{pH}$ gradient or IAA concentration gradient which was given in the surrounding medium. These two chambers of the apparatus were covered with a glass slip, and four stop cocks of the apparatus were also closed usually. Each experiment was carried out in the two cases: first, the case in which the apical end of the cell was set in A chamber, and second, the case in which the basal end of the cell was set in A chamber. All experiments were tried at room temperature under diffuse light of about 80 lux.

\section{Results}

The materials which were cultured under $\mathrm{pH}$ gradient or IAA concentration gradient as mentioned above were able to grow and develop a new shoot and rhizoids. According to the results attained by the present experiment the polarity of morphogenesis was different from the natural one. A new shoot and rhizoids arose from the end which was placed in more favourable medium whether this end was apical or basal.

\section{Effect of pH gradient}

Figure 2 shows the end from which a new shoot and rhizoids were formed in the cell that was cultured under $\mathrm{pH}$ gradient. In this figure, (S) represents shooting and $(\mathrm{R})$ indicates rhizoid formation. For example, in Experiment 1 (Combination $\mathrm{pH}$ $4.0: \mathrm{pH}$ 6.6) of this figure it is recognizable that a new shoot and rhizoids arose from the end of the cell portion which was placed in the medium buffered at $\mathrm{pH}$ 6.6.

In Control and Experiment 5, shooting generally took place at the apical end and rhizoid formation occurred at the basal end according to the natural polarity. In the other case, however, the natural polarity disappeared. Judging from the results, it seems that a new shoot and rhizoids are formed from the end which is 
A $\quad$ B

Control

Experiment 1

Experiment 2

Experiment 3

Experiment 4

Experiment 5

$$
\begin{array}{ll|ll}
\mathrm{pH} & 6.6(\mathrm{~S} \text { or } \mathrm{R}) & \mathrm{pH} & 6.6(\mathrm{R} \text { or } \mathrm{S})
\end{array}
$$

\begin{tabular}{|l|ll|}
\hline 4.0 & $6.6 \quad(\mathrm{~S})(\mathrm{R})$ \\
\hline
\end{tabular}

\begin{tabular}{|l|l|}
\hline 5.0 & $6.6(\mathrm{~S})(\mathrm{R})$ \\
\hline
\end{tabular}

\begin{tabular}{l|ll}
\hline 7.6 & $6.0 \quad(\mathrm{~S})(\mathrm{R})$ \\
\hline
\end{tabular}

\begin{tabular}{l|ll}
5.0 & $7.6(\mathrm{~S})(\mathrm{R})$
\end{tabular}

$7.6(\mathrm{~S}$ or $\mathrm{R}) \quad 6.6(\mathrm{R}$ or $\mathrm{S})$

Fig. 2. Shooting and rhizoid formation in the cells which were cultured under $\mathrm{pH}$ gradient

placed in the medium at or around $\mathrm{pH}$ 6.6.

The rate of the protoplasmic streaming in the cell was generally constant except for two or three days at the start of cultivation, when it decreases, and for several days prior to shooting, when it increases, in all cases. And there was no difference in the rate of streaming between the portion that was placed in $\mathrm{A}$ chamber and the portion in $\mathrm{B}$ chamber. The decrease in the rate of streaming is probably due to the mechanical shock accompanying the culture treatment. The time required by the material for shooting or forming rhizoids after it was brought into the culture medium, and the constant velocity of the protoplasmic streaming in each case are summarized in Table 1.

Table 1. Time required by the cells, which were cultured under $\mathrm{pH}$ gradient, for shooting or rhizoid formation, and the constant velocity of the protoplasmic rotation

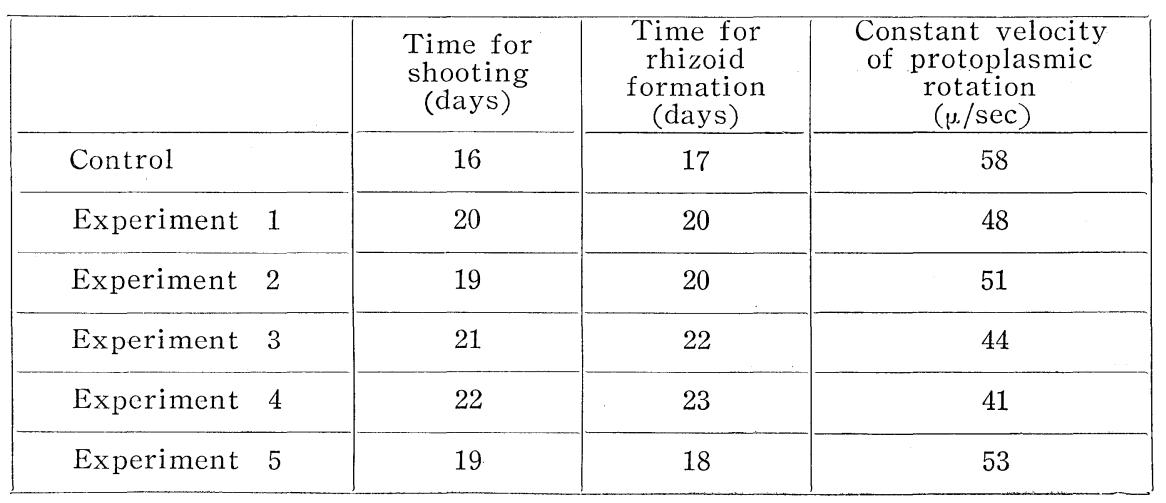




\section{Effect of IAA concentration gradient}

Figure 3 shows the end at which the new development occurred in the cell that was cultured under IAA concentration gradient. In Control, Experiment 1 and Experiment 5, a new shoot was formed from the apical end of the cell and rhizoids arose from the basal end according to the natural polarity. However, the natural polarity was lost in other cases. Considering the results, it seems that a new shoot and rhizoids are ready to be formed from the end which is placed in the medium containing about $0.1 \mathrm{mg} . / 1$. IAA.

Similarly to the case in which $\mathrm{pH}$ gradient was applied, the rate of protoplasmic streaming in the cells which were cultured under IAA concentration gradient was generally constant except for two or three days at the start of cultivation and for several days prior to shooting. However, in Experiments 1, 2 and 3 the rate of flow

A

$\mathrm{B}$

\begin{tabular}{|c|c|c|c|c|c|}
\hline & & & & & \\
\hline Control & & $0 \mathrm{~m}$ & $(\mathrm{~S}$ or $\mathrm{R})$ & $0 \mathrm{mg}$ & $(\mathrm{R}$ or $\mathrm{S})$ \\
\hline Experiment & 1 & 0 & $(\mathrm{~S}$ or $\mathrm{R})$ & 0.05 & $(\mathrm{R}$ or $\mathrm{S})$ \\
\hline Experiment & 2 & 0 & & 0.1 & (S) (R) \\
\hline Experiment & 3 & 0 & & 5.0 & (S) (R) \\
\hline Experiment & 4 & 0.1 & $(\mathrm{~S})(\mathrm{R})$ & 5.0 & \\
\hline Experiment & 5 & 0.1 & (S or $\mathrm{R}$ ) & 0.5 & $(\mathrm{R}$ or $\mathrm{S})$ \\
\hline
\end{tabular}

Fig. 3. Shooting and rhizoid formation in the cells which were cultured under IAA concentration gradient

Table 2. Time required by the cells, which were cultured under IAA concentration gradient, for shooting or rhizoid formation, and the constant velocity of the protoplasmic rotation

\begin{tabular}{|c|c|c|c|}
\hline & $\begin{array}{l}\text { Time for } \\
\text { shooting } \\
\text { (days) }\end{array}$ & $\begin{array}{l}\text { Time for } \\
\text { rhizoid } \\
\text { formation } \\
\text { (days) }\end{array}$ & $\begin{array}{l}\text { Constant velocity } \\
\text { of protoplasmic } \\
\text { rotation } \\
(\mu / \mathrm{sec}))\end{array}$ \\
\hline Control & 16 & 17 & 58 \\
\hline Experiment 1 & 17 & 17 & 58 \\
\hline Experiment 2 & 19 & 18 & 56 \\
\hline Experiment 3 & 20 & 19 & 50 \\
\hline Experiment 4 & 19 & 21 & 52 \\
\hline Experiment 5 & 17 & 18 & 56 \\
\hline
\end{tabular}


in the portion which was placed in $B$ chamber (containing IAA) was slightly larger than that in the portion in A chamber (containing no IAA) for three or four days after recovery to the normal rate from the diminished rate, which is probably due to the mechanical shock accompanying the culture treatment. But the velocity of the portion in $\mathrm{B}$ chamber soon became slow and reached the same value as that of the portion in A chamber. The time required by the materials for shooting or forming rhizoids and the constant velocity of the protoplasmic rotation are shown in Table 2.

\section{Discussion}

A new rhizoid was formed from the portion in the medium of strong acidity when the fertilized egg of Fucus was placed in the medium in which $\mathrm{pH}$ gradient was given: $\mathrm{pH} 5.8$ at one side of the egg and $\mathrm{pH} 8.3$ at the opposite side (Whitaker, 1937). In the present work using Nitella cell, a shoot and rhizoids arose from the end which was placed in the medium at $\mathrm{pH} 6.6$ or around 6.6. Sandan and Ogura (1957) reported that the most suitable $\mathrm{pH}$ for the morphogenesis of the cell of Nitella is around 6.6. Olson and duBuy (1937) observed that when fertilized egg of Fucus was placed near a capillary which was filled with sea water containing $\beta$ IAA, a new rhizoid arose from the portion near the capillary. Overbeek (1940) mentioned that rhizoid formation in various algae ordinarily arises at the portion containing a large amount of IAA. Bünning (1952) said that the factor controlling polarity in plant may be unequal distribution of IAA.

According to the results obtained from the present work, a shoot and rhizoids in the Nitella cell, which was cultured under IAA concentration gradient, were formed from the end that was placed in the medium containing about $0.1 \mathrm{mg}$./1. IAA. The appropriate concentration of IAA for the morphogenesis of the cell is $0.1-0.3 \mathrm{mg} . / 1$. (Sandan and Ogura, 1957). Thus, a new shoot and rhizoids in the isolated cell of Nitella, which was cultured under $\mathrm{pH}$ gradient or IAA concentration gradient, arose from the end that was placed in adequate medium, whether this end was apical or basal.

The morphogenesis and the protoplasmic streaming in Nitella cell were accelerated by application of IAA in low concentrations (Sandan and Ogura, 1957). In the present work, however, the velocity of protoplasmic streaming in the cells which were cultured under IAA concentration gradient was not larger than that in the control cell. Further, in the case of control, a shoot and rhizoids were formed earlier than in all the other cases. It is likely that the cell is liable to be hurt when its two ends are brought into contact with solutions of IAA of different concentrations even though each of the concentrations is favourable for morphogenesis. This is also true for $\mathrm{pH}$.

Artificial control of morphogenetic polarity in Nitella cell was also attained by the experiment of Sandan (1955) who found the following phenomena: When the isolated internodal cell of Nitella was cultured in the vertical, normal position. a new 
shoot generally arose from the apical end and rhizoids appeared from the basal end, but when the cell was cultured in the vertical, inverted position and the lower half of the cell was kept dark, a new shoot was formed from the upper end, which is actually the basal end, and rhizoids arose from the lower end, which is actually the apical end.

It has been well known that rhizoid formation of spore cell in such lower plants as Equisetum, Cystoseira, Anthoceros, Laurencia, Marchantia, Fucus and Bryopsis occurs at the dark portion of spore cell (Stahl, 1885; Peirce and Randolph, 1906; Hund, 1931; Steinecke, 1925 ; Knapp, 1931; Bloch, 1934 ; White, 1934).

In the light of the present experiment and of the previous work with special reference to the reversal of morphogenetic polarity by changing light condition (Sandan 1955), we are now in a position to say that the morphogenetic polarity in Nitella cell is certainly weak and is easily controlled by artificial treatment.

\section{Summary}

When the isolated internodal cell of Nitella flexilis was cultured under $\mathrm{pH}$ gradient or IAA concentration gradient, which was given in culture medium, a new shoot and rhizoids were formed from the end which was placed in more adequate medium, whether this end was apical or basal. Sandan (1955) found that the morphogenetic polarity of the cell can be reversed by changing light condition. In the light of these experiments we are now in a position to say that the mor phogenetic polarity in the cell of Nitella is certainly weak and is easily controlled by artificial treatment.

The author wishes to express his most cordial thanks to Prof. N. Kamiya of Osaka University for his kind direction and helpful criticism throughout this work and also to Prof. T. Nakamura for his valuable advice.

\section{References} 1) Bloch, R., Bot. Rev. 9: 261 (1934).
2) Bünning, E., Surv. Biol. Prog. 2: 105 (1952). 3)
Hund, A. M., Bot. Gaz. $70: 25$ (1931).
4) Knapp, E., Planta i4: 731 (1931). 5) Olson, R. A. and DuBuy, H. G., Amer. J. Bot. 24:611 (1937). 6) Overbeek, J., Plant Physiol. 15: 291 (1940). 7) Peirce, G. J. and Randolph, E. A., Bot. Gaz. 40:391 (1906). 8) Sandan, T., Bot. Mag. Tokyo 68: 274 (1955). 9) —, ibid 69: 307 (1956). 10) _— and Ogura, T. ibid 70:125, (1957). 11) Stahl, E., Ber. Deut. Bot. Gesel. 3:334 (1885). 12) Steinecke, E., Bot. Arch. 12: 97 (1925). 13) Whitaker, D. M., Biol. Bull. 73 : 294 (1937). 14) White, P. R., Plant Physiol. 9: 585 (1934). 